világérzés legreprezentatívabb példái. Gregor Strniša költészete az emberi lét kérdéseit egyrészt kozmikus, másrészt mitológiai dimenzióba emeli, és az általa használt versforma (négysoros versszakok, asszonáns verssorok) is a huszadik század második felének egyik legeredetibb szlovén költőjévé avatja.

Mivel a válogatás a huszadik század tízes, húszas és harmincas éveiben született szerzők életmüvét öleli fel, a könyvben publikált müvek a huszadik század második felének csaknem teljes egészét reprezentálják. Ennek legjobb példája Kajetan Kovič versei, amelyek poétikájában az erőteljes személyesség mellett tükröződik a korszak szlovén lírájának fejlödése is, hiszen egy fél évszázad alatt születtek. Ugyanígy említhetnénk Veno Taufer itt szereplő két versét is, amelyeket ebben az időszakban a közép-európai térség két legszörnyübb tragédiája, az ötvenhatos magyar felkelés és a kilencvenes évek eleji vukovári tragédia emlékének ajánlott a szerző.

Végül említsük meg a huszadik század drámai pillanatainak három hiteles tanúját, Boris Pahort, Vitomil Zupant és Lojze Kovačičot. A háború kataklizmáját és az azt követő szocializmus korszakát, amely korántsem volt olyan idilli, mint amilyennek saját magát hirdette, mindhárman személyes tapasztalatként élték meg. Az autentikus élettapasztalattal hitelesített általános emberi problematika e szerzők (különösen Kovačič és Pahor) prózájában Európa-szerte jelentős visszhangra talált.

Az antológia az egyetemistáknak jóval több mint ajánlott olvasmány, ám kétségtelenül érdekes lehet azoknak az olvasóknak is, akiknek az irodalom csupán kellemes időtöltést jelent, hiszen olyan müveket tartalmaz, amelyek témája, üzenete és nem utolsósorban esztétikai minősége mindenki számára vonzó lehet.

\section{Peter Svetina}

Alpen-Adria-Universität Klagenfurt Peter.Svetina@uni-klu.ac.at

\section{POROČILO Z DNEVOV MAKSA PLETERŠNIKA: IZZIVI SODOB- NEGA SLOVENSKEGA SLOVARO- \\ PISJA. Pišece, 13. in 14. 9. 2010}

Filozofska fakulteta Univerze v Mariboru, Društvo za varovanje maternega jezika in kulturne dediščine Maksa Pleteršnika ter Strokovni odbor Maksa Pleteršnika so 13. in 14. 9. 2010 pripravili tradicionalni septembrski znanstveni sestanek Dnevi Maksa Pleteršnika. Po šestih strokovnih srečanjih (prvo je bilo leta 1994) je bilo letošnje posvečeno aktualnim vprašanjem slovenskega slovaropisja - Izzivi sodobnega slovenskega slovaropisja.

V Pišecah, rojstnem kraju Maksa Pleteršnika (3. 12. 1840-13. 9. 1923), se je dvodnevnega sestanka udeležilo 38 slovenskih in uglednih tujih strokovnjakov jezikoslovcev (12 iz tujine - Poljske, Nemčije, Danske, Madžarske, Makedonije, Južnoafriške republike).

Kot cilje znanstvenega simpozija je Marko Jesenšek, vodja simpozija, navedel razmišljanje o semantični klasifikaciji in leksikografiji, strokovnem izrazju in obvestilnosti sodobnega pravopisnega slovarja, slovaropisni problematiki etimoloških slovarjev, slovenskih narečnih slovarjih, zgodovinskih slovarjih. Pri tem gre za (1) vprašanja, ki so povezana s posodobitvijo že obstoječih 
slovarskih del, in (2) raziskovalne izzive, ki jih predstavljajo novosti na področju historične leksikografije, vključujoč narečno in etimološko področje.

Simpozij je s prispevkom Škrabec o zaznamovanju naglasov v Pleteršnikovem slovarju odprl Jože Toporišič, prvi predsednik leta 1992 ustanovljenega Organizacijskega in operativnega odbora Maksa Pleteršnika. O vprašanjih poznavanja jezikovnega sestava, jezikovnega razvoja in besedil za primerno slovarsko delo je razpravljal France Novak. Opozoril je na dejstvi, da se s slovaropisjem ukvarja vse več ljudi in da bi bilo potrebno v specialno izobraževanje v večjem obsegu vključiti dejanske potrebe slovarskega dela, ki so različne za posamezna področja in posamezniku vidne šele, ko se začne s tem ukvarjati. Slovarji po njegovem odgovarjajo na potrebe, ki so v njihovem času nastajanja aktualne. S temo sodobnega slovaropisja $\mathrm{v}$ povezavi s spletom se je ukvarjala Mija Michelizza. Ugotovila je, da so besedilni korpusi temeljna podlaga za nastanek sodobnega slovarja in da vedno več korpusov v svojo sestavo vključuje določen del spletnih besedil. Ker je danes zbiranje gradiva na spletu precej olajšano, se je dotaknila novosti in možnosti, ki jih takšna oblika prinaša, ter vloge uporabnikov pri nastajanju slovarjev. Iztok Kosem je spregovoril o prihodnosti leksikografije - o dinamičnem slovarju, katerega vsebina se prilagaja vsakemu uporabniku posebej. Izpostavil je dejstvo, da so slovarji, kljub temu da so pri njihovi izdelavi izkoristili tehnološki napredek in ponudili uporabnikom elektronske slovarje (načelo: en slovar za več uporabnikov), le-ti pogosto zgolj papirnati slovarji, ki so preneseni v elektronsko obliko, s tem pa velik del potenciala elektronskih medijev ostaja neizkoriščen. To ostaja še vedno izziv za leksikografe današnjega časa. Povezavo slovarjev, učiteljev in šolarjev sta na osnovi projekta Evalvacija vzgoje in izobraževanja v Republiki Sloveniji, ki je potekal leta 2008, predstavila Marko Stabej in Tadeja Rozman. $\mathrm{S}$ sociolingvističnega vidika sta podala najpomembnejše rezultate in podatke o tem, kako in katere slovarske priročnike uporabljajo udeleženci šolskega procesa (učitelji najpogosteje SSKJ in SPS, pri učencih pa prevladuje e-oblika), kako dojemajo slovarje in kakšno vlogo jim pripisujejo. Tadeja Rozman je v prispevku z naslovom Razumi, kdor more (razumljivost slovarskih definicij $v$ šolski praksi) prikazala empirične rezultate svoje doktorske raziskave in pokazala pomanjkljivosti, ki so v veliki meri povezane s tem, da je SSKJ (predvsem zaradi slabe razumljivosti slovarskih podatkov) neprimeren za šolarje. Zagovarjala je misel o potrebnosti oblikovanja posebnih slovarjev, ki bi bili namenjeni šolarjem in bi služili kot pomoč pri razumevanju in rabi besed. O problemu obvestilnosti sodobnega pravopisnega slovarja je spregovorila Helena Dobrovoljc. Predstavila je pojem slovarska obvestilnost in ponazorila razliko med pomenskorazlagalnimi enojezičnimi slovarji (npr. SSKJ) ter specializiranimi slovarski deli (npr. pravopisni slovar). Aleksandra Bizjak Končar se je dotaknila problema razporeditve ilustrativnega gradiva $v$ splošnem razlagalnem slovarju slovarskega jezika. Takšno gradivo namreč postaja vse pomembnejši del slovarskega sestavka, saj jezik ni le sistem abstraktnih pravil, ampak družbeni pojav, ki se uresničuje v besedilih - rabi. Ilustrativno gradivo je podrejeno strogim načelom izbora, zato prispevek proučuje spremenljivke, ki odločilno vplivajo na razporeditev takšnega gradiva pri različnih besedah v 
splošnem razlagalnem slovarju slovenskega jezika (SSKJ). Tema Mojce Žagar Karer so bile Definicije v slovenskih terminoloških slovarjih. Ena najpomembnejših in najtežjih nalog terminologov in terminografov je definiranje pojma. Slednje temelji na analizi pojmov, te pa je potrebno uvrstiti v pojmovni sistem stroke in jasno nakazati razmerja med posameznimi pojmi. Opisala je tri glavne tipe definicij, ki se uporabljajo v terminologiji: intenzijsko, ekstenzijsko in intenzijsko-ekstenzijsko. Marjeta Humar je analizirala poimenovanja za moške in ženske $\mathrm{v}$ novejših slovarskih terminoloških slovarjih. Ugotovila je, da je v javni rabi jezika močno poudarjena enakopravna uporaba poimenovanj za ženske in moške (npr. zdravnik - zdravnica). Pri analizi slovarjev je prišla do zaključka, da se število poimenovanj za ženske osebe $v$ novejših slovarjih povečuje, da so prikazi v slovarjih različni (glede na način in od tega, kdo je v skupini sestavljalcev) in da sodobni slovenski terminološki slovarji razmeroma pogosto izkazujejo obe obliki. Mojca Tomišić je v prispevku z naslovom Tipologija prikaza glagolov s se v novem slovarju slovenskega jezi$k a$ pod drobnogled vzela Pleteršnikov Slovensko-nemški slovar, SSKJ in Slovenski pravopis. Na temelju teoretičnih predpostavk in izdelane kategorizacije glagolov s se (oblikoslovno-skladenjski in pomenski kriterij) je utemeljila štiri tipe slovarskega prikaza glagolov s se. Edina slovarja za makedonščino in slovenščino je predstavil Gjoko Nikolovski. Zanimiva se mu zdi ugotovitev, da se od prvega makedonskega slovarja (1982) do danes v kontekstu makedonsko-slovenske leksikografije ni nič spremenilo, poudarja, da bi bilo potrebno izdati dva nova slovarja: makedonsko-slovenskega in obratno, ta pa bi se morala opirati na zadnjo izdajo pravopisov obeh jezikov in na njune sodobne slovarje. Dorota Chłopek in Emil Tokarz sta predstavila učenje angleščine kot tujega jezika. S primeri sta ponazorila, kako lahko angleški internetni enojezični slovarji sprožijo gradnjo pomena besed. Osredotočila sta se na kategorizacijo in ne na analizo strukture internetnih slovarjev, pri tem pa sta prikazala posamezne interne slovarje in jih komentirala. Mateusz Warchał se je ukvarjal s problematiko pedagoškega diskurza. Razprave Poljakov Krzysztofa Feruge (Molizańska leksykografia), Liborja Pavera (K terminologii neologismu v poetice a stylistice) in Przemyslawa Broma (Czarnagórska leksykografia - wybrane zagadnienia) bomo lahko prebrali v simpozijskem zborniku.

Drugi dan simpozija sta s prispevkoma (Slovenski narečni slovarji: kako je in Slovenski narečni slovarji: kako naj bi bilo) v soavtorstvu nastopila Karmen Kenda-Jež in Peter Weiss. Sistematično in natančno sta pokazala, kaj Slovenci na področju narečnega slovaropisja imamo in kaj nam manjka. Izpostavila sta dejstvo, da število narečnih slovarjev vedno bolj narašča. Opozorila sta na zgolj točkovno pokrivnost slovenskega jezikovnega ozemlja, v povprečju na še vedno nastajajoče razlikovalne enonarečne ljubiteljske slovarje s preprosto geselsko strukturo, na premalo elektronskih in spletnih narečnih slovarjev, na pomanjkanje posnetkov $\mathrm{v}$ digitalni obliki, na to, da nimamo prosto dostopnih programov za sestavo narečnih slovarjev ipd. Vse to po njunem mnenju predstavlja izzive za narečno leksikografijo v prihodnosti. Na področju narečnega slovaropisja smo Slovenci v letu 2009 dobili Slovar Gornjega Senika, ki ga je predstavila avtorica Marija Bajzek Lukač. Povedala je, da število govor- 
cev tega slovenskega govora na ozemlju Madžarske vidno upada, zato je projekt zbiranja besed in zapis zbranega gradiva v obliki narečnega slovarja še kako pomemben. Prispevek Anje Benko in Zinke Zorko se je navezoval na porabščino. Analizirani so bili madžarizmi v prvem porabskem romanu Garaboncijaš (2005). Ugotovili sta, da prevladuje splošno slovensko besedje s številnimi panonizmi, med prevzetimi besedami so številni germanizmi, manj je madžarizmov. Slednji so bili preverjeni še v Pleteršnikovem slovarju. Anja Benko in Mihaela Koletnik sta poskušali podati teoretična izhodišča za izdelavo primerjalnega terminološkega narečnega slikovnega slovarja in to ponazoriti na vzorcu besedja s področja poljedelstva $\mathrm{v}$ izbranih govorih panonske in koroške narečne skupine. Takšne primerjave besedja $\mathrm{v}$ slovenskem narečnem prostoru bi lahko v prihodnosti omogočale določitev arealov posameznih leksemov in njihovega pomenskega obsega, s tem pa pripomogle $\mathrm{k}$ zamisli o slovenskih narečnih izrazijskih slovarjih. Osnutek terminološkega narečnega ribiškega slovarja govorov Tržaškega zaliva je predstavila Rada Cossutta. Opredelila je postopek nastajanja tega slovarja, ki je še v pripravljalni fazi. V strokovnem ribiškem izrazju se na pristnem slovanskem jezikovnem fondu prepletajo romanske in germanske prvine, to pa priča o dolgoletnih stikih naših ribičev s tujimi in predstavlja bogato kulturno dediščino. Danila Zuljan Kumar se je osredotočila na besedje s tematiko sadovnjak, vrt, polje in živali v govoru Medane (briško narečje). Analizirala je transkripcijo govorjenega besedila, $v$ obliki geselskih člankov prikazala besedje za izbrano tematiko, v zadnjem delu pa zbrano besedje analizirala na besednovrstni in besedotvorni ravnini.
Projekt Kako se pri vas reče?, ki ga je v 34 vaseh petih gorenjskih občin leta 2009 izvedla Razvojna agencija Zgornje Gorenjske in v katerem je bilo zbranih 994 hišnih imen, je predstavila Jožica Škofic. Pogled na slovensko zgodovinsko slovaropisje - stanje in perspektive je bila tema Irene Orel. Prikazala je sedanji razpoložljivi in predvideni obseg slovenskega zgodovinskega slovaropisja. Opozorila je, da bi slovenski zgodovinski slovar moral biti zasnovan kronološko in da se je število slovenskih zgodovinskih slovarskih zbirk v zadnjem desetletju močno povečalo, predvsem z digitalizacijo starejših slovarjev ter besedil. Vlogi kazalk v slovenskem (zgodovinskem) slovaropisju se je posvetila Majda Merše. Kazalke, ki so običajna sestavina slovaropisne metodologije in eden od nosilcev slovarske obvestilnosti, imajo v slovarju namen, ki je odvisen od zasnove in tipa slovarja. Povedala je, da pripravljajo popis besedja, ki je uporabljeno $\mathrm{v}$ tiskih $\mathrm{s}$ slovenskim besedilom iz druge polovice 16. stoletja, in prikazala, kako bo zajeto besedje opremljeno z besednovrstnimi in drugimi slovničnimi oznakami ter s podatki o virih, vse to pa terja rabo kazalčnih gesel. S prispevkom Časopisje kot slovarski vir Pleteršnikovega Slovensko-nemškega slovarja je nastopila Natalija Ulčnik. Sodobni eno- in večjezični slovarji večinoma že temeljijo na elektronskih zbirkah besedil korpusih, ti pa v slovenskem prostoru $\mathrm{v}$ veliki meri zajemajo publicistične, zlasti časopisne vire (okoli $80 \%$ ). Pregledala je, v kakšnem obsegu in kako je zastopano časopisno gradivo v Pleteršnikovem slovarju, in ugotovila, da so zajeti vsi pomembnejši časopisi druge polovice 19. stoletja. Kristina Šter se je posvetila živalski frazeologiji (frazemi s sestavino domače živali) v Glonarjevem 
slovarju in primerjavi te s Pleteršnikovim, z Murkovim in Gutsmanovim slovarjem ter z Metelkovo slovnico. Ugotoviti je želela, na koga se Glonar navezuje in kako, prav tako jo je zanimalo stanje $\mathrm{v}$ sodobnem slovenskem jeziku. Zgodovinsko slovaropisje - med narečjem in knjižnim jezikom je bila tema Marka Jesenška. Poudaril je, da je potrebno izdelati enotni vzorec pisanja zgodovinskih slovarjev (s tem bi imeli kasneje več možnosti združevanja). Prav tako bi morali izdelati natančno teoretično osnovo za slovar in hkrati z njegovo tiskano različico pripravljati tudi elektronsko. Pri tem se moramo po njegovem mnenju Slovenci bolj nasloniti na teorijo slovarske oblike (npr. Weigand) in funkcijsko teorijo slovarja (npr. Bergenholtz, Tarp).

$\mathrm{Na}$ znanstveni sestanek so se s prispevki prijavili tudi naslednji avtorji: Irena Stramljič Breznik (Besedotvorni procesi slovenskega jezika na prelomu stoletja z vidika Pleteršnikove slovarje oznake novoknjižno), Alenka Šivic Dular ( $K$ razvoju psl. glagolov na -noti v slovenščini), Donald F. Reindl (Mycological Terminology in Maks Pleteršnik's Slovenian-german Dictionary), Kathrin Steyer (Korpusbasierte Erhebung lexicographisch relevanter Sprachdaten), Erla Hallsteinsdóttir (Deutsch-isländische Lexikographie/Nemško-islandsko slovaropisje), Rufus H. Gouws (Expanding the scope of the application of enrichment in dictionary articles) in Lidija Arizankovska (Makedonsko in slovensko slovaropisje), a se srečanja niso udeležili. Morda bomo lahko njihove prispevke prebrali v simpozijskemu zborniku.

V Pišecah, ki so se v čast Maksa Pleteršnika za dva dni ponovno spremenile v slovaropisno vas, so bili prikazani in predstavljeni problemi, projekti, raziskave ..., ki se dotikajo leksikografije in z njo povezanih jezikoslovnih panog. $\mathrm{Na}$ znanstvenem sestanku so se udeležencem porajala številna vprašanja, določene dileme so še vedno ostale odprte, nekatera slovaropisna področja pri nas še kažejo primanjkljaj. Sama sem pogrešala več metodoloških napotkov za izdelavo (narečnih) slovarjev in raziskave, ki bi se opirale na dobra teoretična izhodišča, temelječa na sodobni in aktualni slovaropisni teoriji. Ciljev, ki si jih je zadal vodja sestanka, Marko Jesenšek, smo se dotaknili, nismo pa jih v celoti dosegli ali celo presegli. Tematika ostaja še naprej odprta in kliče po novih srečanjih.

Anja Benko

Univerza v Mariboru, Filozofska fakulteta, anja.benko@gmail.com 